\section{Pacific Northwest}

National Laboratory

Operated by Battelle for the

U.S. Department of Energy
Results of Tritium Tracking and

Groundwater Monitoring at the Hanford Site 200 Area StateApproved Land Disposal SiteFiscal Year 2001

D. B. Barnett

J. T. Rieger

October 2001

Prepared for the U.S. Department of Energy under Contract DE-AC06-76RL01830 


\section{DISCLAIMER}

This report was prepared as an account of work sponsored by an agency of the United States Government. Reference herein to any specific commercial product, process, or service by trade name, trademark, manufacturer, or otherwise does not necessarily constitute or imply its endorsement, recommendation, or favoring by the United States Government or any agency thereof, or Battelle Memorial Institute.

\section{PACIFIC NORTHWEST NATIONAL LABORATORY \\ operated by \\ BATTELLE \\ for the \\ UNITED STATES DEPARTMENT OF ENERGY \\ under Contract DE-AC06-76RL01830}

Printed in the United States of America

Available to DOE and DOE contractors from the

Office of Scientific and Technical Information, P.O. Box 62, Oak Ridge, TN 37831; prices available from (615) 576-8401.

Available to the public from the National Technical Information Service, U.S. Department of Commerce, 5285 Port Royal Rd., Springfield, VA 22161 


\title{
Results of Tritium Tracking and Groundwater Monitoring at the Hanford Site 200 Area State- Approved Land Disposal Site-Fiscal Year 2001
}

\author{
D. B. Barnett \\ J. T. Rieger
}

October 2001

Prepared for

the U.S. Department of Energy

under Contract DE-AC06-76RL01830

Pacific Northwest National Laboratory

Richland, Washington 99352 


\section{Summary}

The Hanford Site 200 Area Effluent Treatment Facility (ETF) processes contaminated aqueous wastes derived from Hanford Site facilities. The treated wastewater occasionally contains tritium, which is not removed by the ETF, and is discharged to the 200 Area State-Approved Land Disposal Site (SALDS). Groundwater monitoring for tritium and other constituents is required by the state-issued permit at 3 monitoring and 19 tritium-tracking wells.

Water level measurements in nearby wells indicates the persistence of a small hydraulic mound beneath the SALDS facility as a result of discharges. This feature is directing groundwater flow radially outward a short distance before the regional northeasterly flow predominates. This condition also places several wells south of the SALDS hydraulically downgradient of the facility. With the continued monitoring of these wells, the network is currently adequate for tracking potential effects of the SALDS on the groundwater.

During FY 2001, tritium activities in the SALDS proximal well 699-48-77A increased (maximum $670,000 \mathrm{pCi} / \mathrm{L}$ ) as a result of the resumption of tritium disposal in September 2000, following a 16-month hiatus in significant tritium discharges. Well 699-48-77C, where tritium results reached a maximum value of $980,000 \mathrm{pCi} / \mathrm{L}$, is reflecting the result of the delayed penetration of effluent deeper into the aquifer from 1999 SALDS tritium discharges. Speculation in FY 2000 that tritium may have reached two wells due south of the facility is probably premature. FY 2001 results indicate no departures from historical levels of tritium in these wells.

Of the 11 constituents with permit enforcement limits, which are monitored in SALDS proximal wells, all were within permit groundwater limitations during FY 2001. Analyses for conductivity, total dissolved solids, chloride, sulfate, dissolved calcium, and dissolved sodium indicate that SALDS proximal wells show the effects of dilute effluent entering groundwater, resulting in a depression of concentrations of these constituents below natural background levels. Earlier elevated levels of these constituents were the result of the dissolution of natural soil salts by SALDS effluent.

Recommendations for future monitoring include retaining in the well network all current tritium tracking wells to the south of the SALDS. This measure will provide accurate determination of the southern bounds of the SALDS-generated tritium plume, provide estimates of travel time for model comparisons, and help preserve the distinction between this plume and the older 200 West tritium plume farther east. 


\section{Acknowledgments}

The author extends his appreciation to reviewers M. J. Hartman (Pacific Northwest National Laboratory) and P. M. Olson (Fluor Hanford, Inc.) and to L. M. Andor and K. R. Neiderhiser (Pacific Northwest National Laboratory) for arrangement and processing of the document. Thanks are also extended to C. A. Newbill for graphics support. 


\section{Contents}

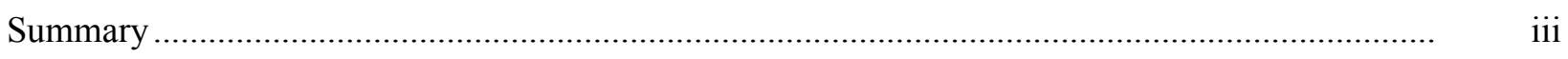

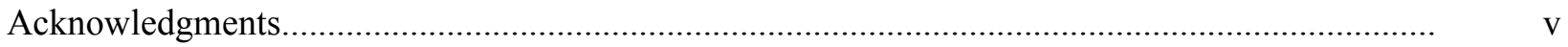

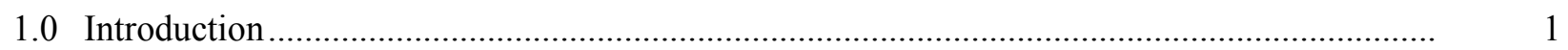

2.0 Water Level Measurement Results ................................................................................ 5

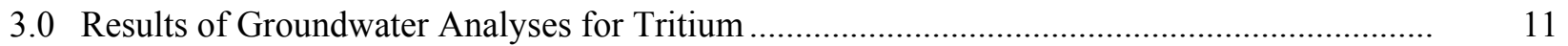

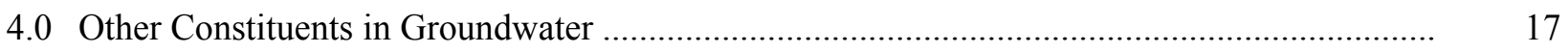

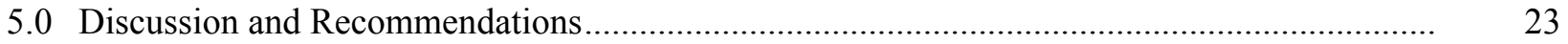

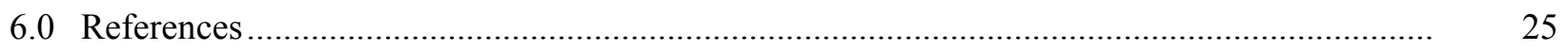

Appendix A - SALDS Tritium Results in Groundwater for FY 2001 .......................................... A.1 


\section{Figures}

1 Location of the State-Approved Land Disposal Site and Related Infrastructure ..................... 2

2 Locations of SALDS Tritium-Tracking Network Wells ..................................................... 3

3 Hydrographs of Tritium-Tracking Wells North, Northwest, and East of the SALDS,

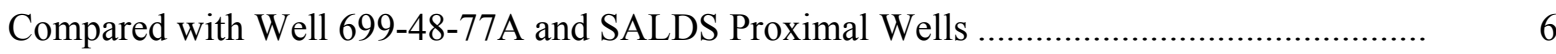

4 Hydrographs of Tritium-Tracking Wells Southwest and South of the SALDS Compared

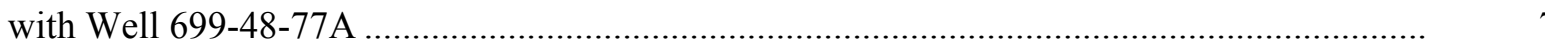

5 Hydrographs of Tritium-Tracking Wells Southeast of SALDS Compared with

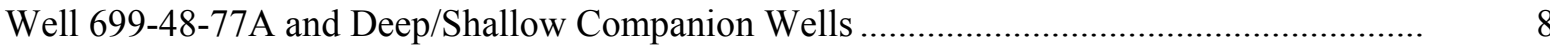

6 Water Table Map and Interpreted Groundwater Flow Directions in the SALDS Area

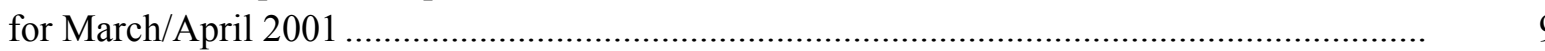

7 Maximum Tritium Activities in Groundwater for the SALDS Tritium-Tracking Network for FY 2001, Indicating Change from FY 2000 ..................................................................

8 Tritium Activity Trends in SALDS Proximal Wells Through August 2001 ........................... 14

9 Tritium Activity Trends in Wells Southeast of the SALDS Showing Remnant Effects of the Tritium Plume from the 200 West Area and Recent Changes in Trends for Wells 299-W7-3 and 299-W7-7

10 Trend Plots for Conductivity and Total Dissolved Solids in SALDS Proximal Wells

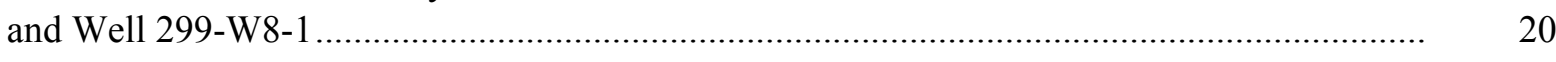

11 Trend Plots for Chloride and sulfate in SALDS Proximal Wells and Well 299-W8-1 ............. 21

12 Trend Plots for Dissolved Calcium and Dissolved Sodium for SALDS Proximal Wells and Well 299-W8-1

\section{Table}

1 Maximum Concentrations of Constituents with Permit Enforcement Limits in Groundwater and Corresponding Sample Month, SALDS, FY 2001 


\subsection{Introduction}

Treated water from the 200 Area Effluent Treatment Facility (ETF) is discharged to a disposal site as allowed by State Waste Discharge Permit ST-4500 (ST-4500). The permit allows disposal of tritium to the disposal site, which is named the State-Approved Land Disposal Site (SALDS), and is located immediately north of the 200 West Area of the Hanford Site (Figure 1). In accordance with ST-4500, the groundwater in the vicinity of the SALDS is routinely sampled and water levels in wells are measured. The results of the groundwater sampling and analysis are reported in quarterly discharge monitoring reports and the annual Hanford Site Groundwater Monitoring Report (e.g., Hartman et al. 2001). In 1997, the U.S. Department of Energy (DOE) also recommended the issuance of an annual summary report of groundwater monitoring results and evaluation, with updates to the groundwater monitoring plan, as appropriate. The following report addresses these recommendations and summarizes the results of groundwater analyses and information for the SALDS during FY 2001.

In August 2000, a renewal of ST-4500 was issued for the ETF and SALDS for years 2000-2005. The new permit effected minor changes in groundwater monitoring at the SALDS, most notably, the elimination of a formerly upgradient well for determination of background groundwater quality. Well 299-W8-1 has not been in the groundwater flow path that incorporates the SALDS since shortly after the beginning of SALDS operation, and thus, did not represent groundwater chemistry upstream of the facility. The list of constituents and the enforcement limits ("groundwater limitations") for concentrations of these constituents remain virtually the same in the new version of ST-4500, except that ammonia was removed from the list. The history of the facility, with respect to groundwater monitoring, and the new groundwater monitoring plan dictated by ST-4500, are described by Barnett (2000a).

Permit ST-4500 contains provisions for update of a numerical groundwater model at least once during a permit cycle (5 years) to predict tritium movement and distribution in the aquifer resulting from SALDS discharges. The permit also requires that the model be reapplied "within 6 months of detection of the tritium plume in a new monitoring well." This provision indicates that the numerical model will be reapplied when the tritium plume associated with the SALDS is positively identified in a location not predicted by the current model run (Barnett et al. 1997) or at a concentration greater than that predicted.

Wells in the groundwater monitoring network (Figure 2) are sampled quarterly to annually for constituents regulated by ST-4500. Wells 699-48-77A, 699-48-77C, and 699-48-77D are part of the proximal monitoring network designed to detect near-term effects on groundwater as a result of the SALDS operation. These three wells are sampled quarterly for tritium and a list of constituents governed by ST-4500. An additional 19 wells are sampled semiannually to annually for tritium only. Wells 299-W7-3, 299-W7-5, 299-7-6, 299-W7-7, 299-7-11, and 699-51-75 are scheduled for semiannual sampling; the remaining 13 wells are sampled annually. Well 699-51-75P, a deep companion to well 699-51-75, was added to the network during FY 2000 to detect tritium deeper within the aquifer. Well 299-W8-1, the former upgradient well, was rescheduled for sampling for tritium only on an annual basis. 


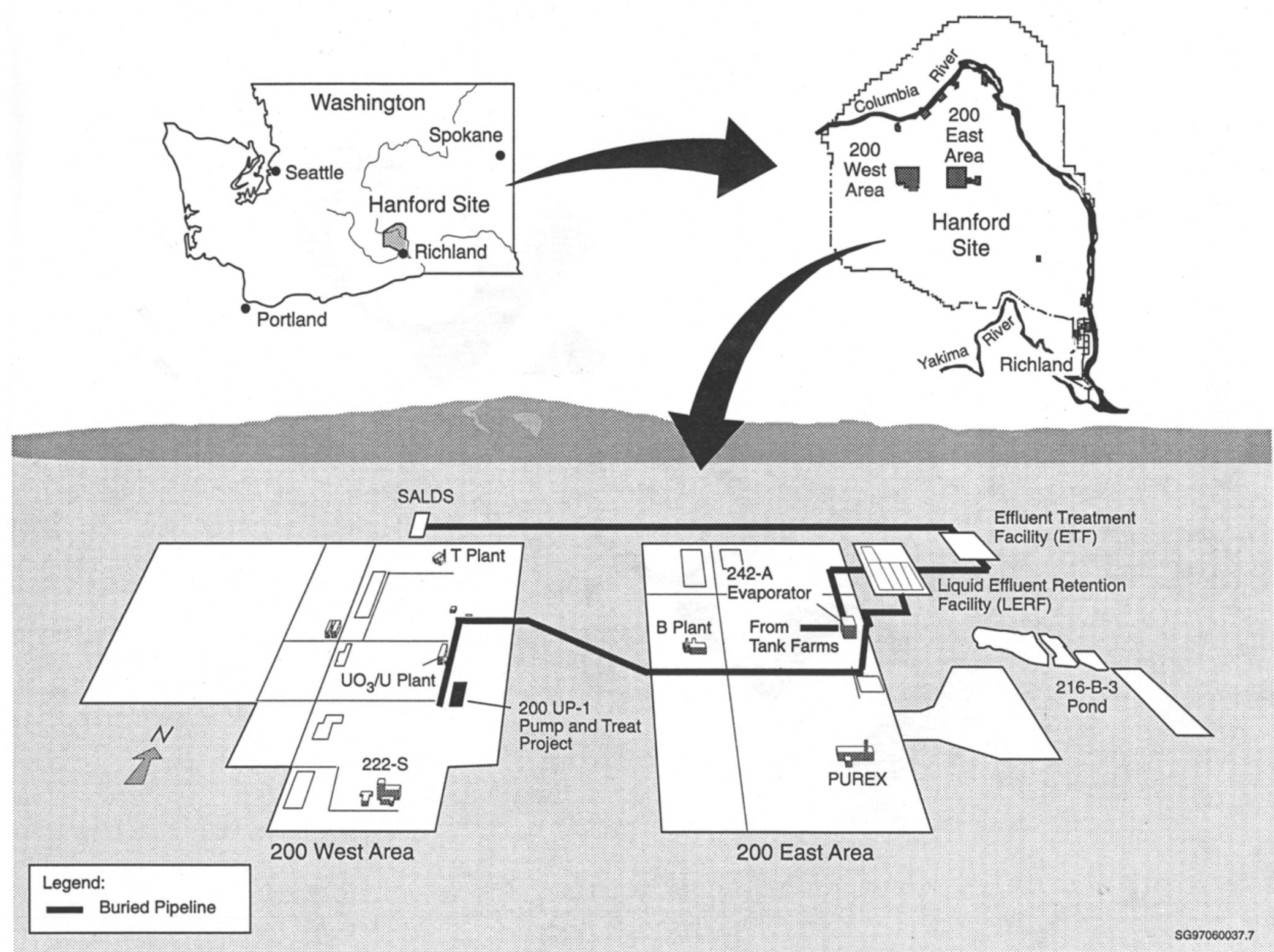

Figure 1. Location of the State-Approved Land Disposal Site and Related Infrastructure 


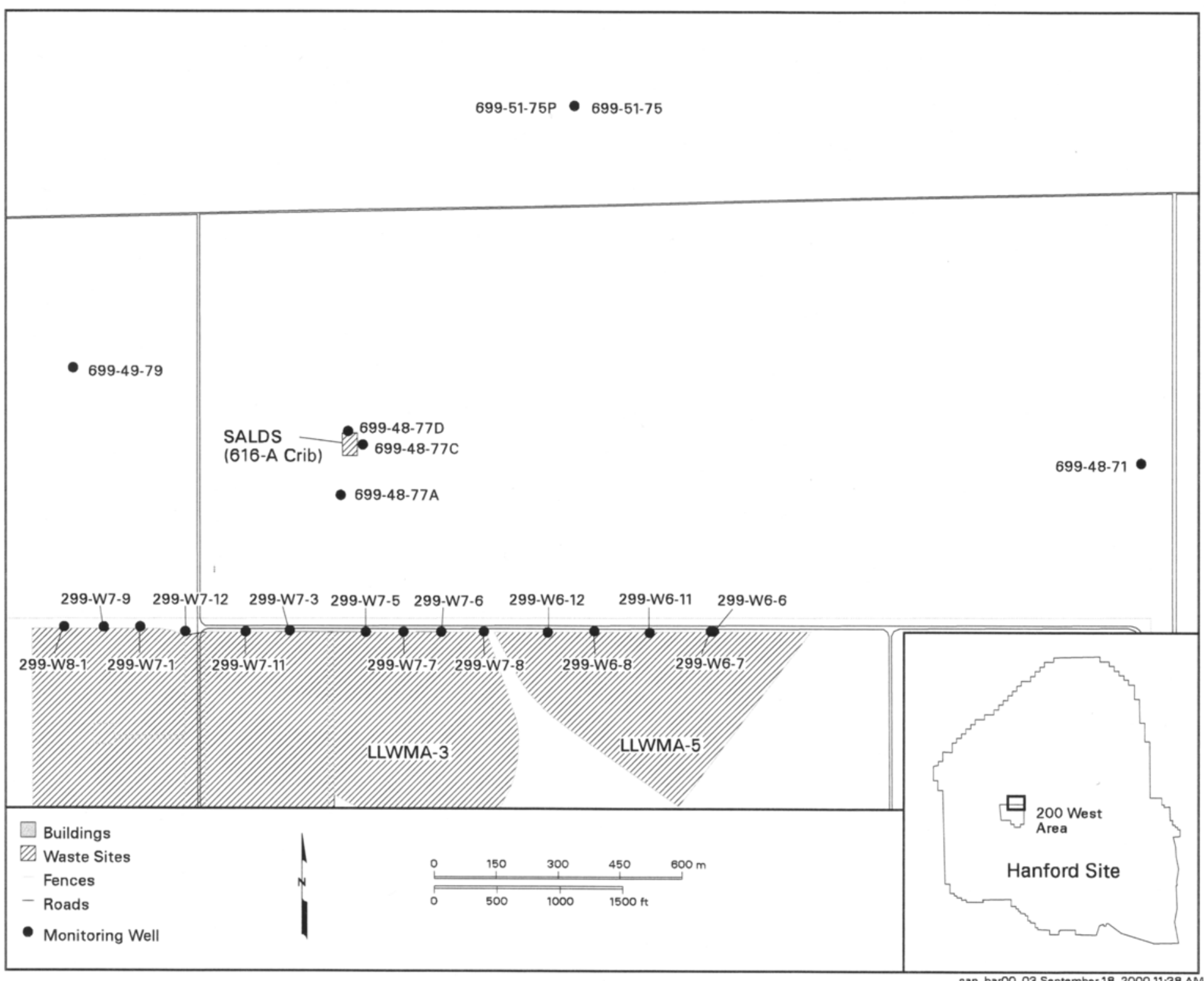

Figure 2. Locations of SALDS Tritium-Tracking Network Wells 


\subsection{Water Level Measurement Results}

Water levels are measured in wells prior to each sampling event. Additionally, water levels have been measured monthly since January 1997 in the proximal SALDS facility wells (699-48-77A, 699-48-77C, and 699-48-77D). Hydrographs for these wells (through August 2001) and the remaining wells in the tritium-tracking network, grouped by relative position to the SALDS, are shown in Figures 3 through 5 .

Hydraulic head level in well 699-48-77A has consistently surpassed the head in most wells in the tritium-tracking network since late 1997 (see Figures 3 through 5). This is a result of the continuing general decline in water levels in the 200 West Area combined with the increased head near the SALDS, resulting from SALDS operation. The current exceptions to this relationship are the wells southwest of the SALDS. In these wells, water level elevations are only intermittently lower than those in well 699-48-77A, depending on the magnitude of discharges to the SALDS.

Hydrographs of deep and shallow tritium-tracking network wells 299-W6-6 and 299-W6-7, respectively, indicate that almost no vertical gradient exists in this portion of the aquifer away from the SALDS vicinity (see Figure 5). Well 299-W6-7 is completed at the water table; well 299-W6-6 is completed $49 \mathrm{~m}$ deeper in the aquifer. This condition explains the lack of tritium from the $200 \mathrm{West}$ Area plume in the deep well, while the shallow well shows high levels of tritium. During operational discharges in the 200 West Area, tritium was apparently not forced down to lower portions of the aquifer in this region. Near the SALDS however, a consistently downward potential exists in the aquifer, as indicated by the head differences between the shallow proximal wells 699-48-77A, 699-43-77D, and deep proximal well 699-48-77C (see Figure 3). For this reason, tritium from SALDS is gradually being forced to lower levels in the aquifer in the immediate vicinity of the facility (see Section 3.0).

An interpretation of the water table in the vicinity of the SALDS for March/April 2001 is shown in Figure 6. The groundwater mound associated with SALDS operation is evident near the facility. The center of the mound is not necessarily located at well 699-48-77A; its shown location is partially an artifact of well coverage at the SALDS and is an approximate location, with the actual center probably located somewhere between well 699-48-77A and the facility. Arrows denoting the interpreted flow paths (or the potential for flow) of groundwater in the vicinity of the SALDS indicate that effluent from the SALDS could eventually affect wells to the south of the facility. Exactly how far south the effluent from SALDS could actually flow before turning east is not known. The interpretation of the flow potential in Figure 6, and hydrographs of Figures 3, 4, and 5, indicate that wells immediately south and southeast of the SALDS are potentially downgradient of the facility. Importantly, downgradient well 699-51-75 is also apparently in an optimum location for the interception and efficient tracking of tritium in a regionally downgradient direction from the SALDS. 

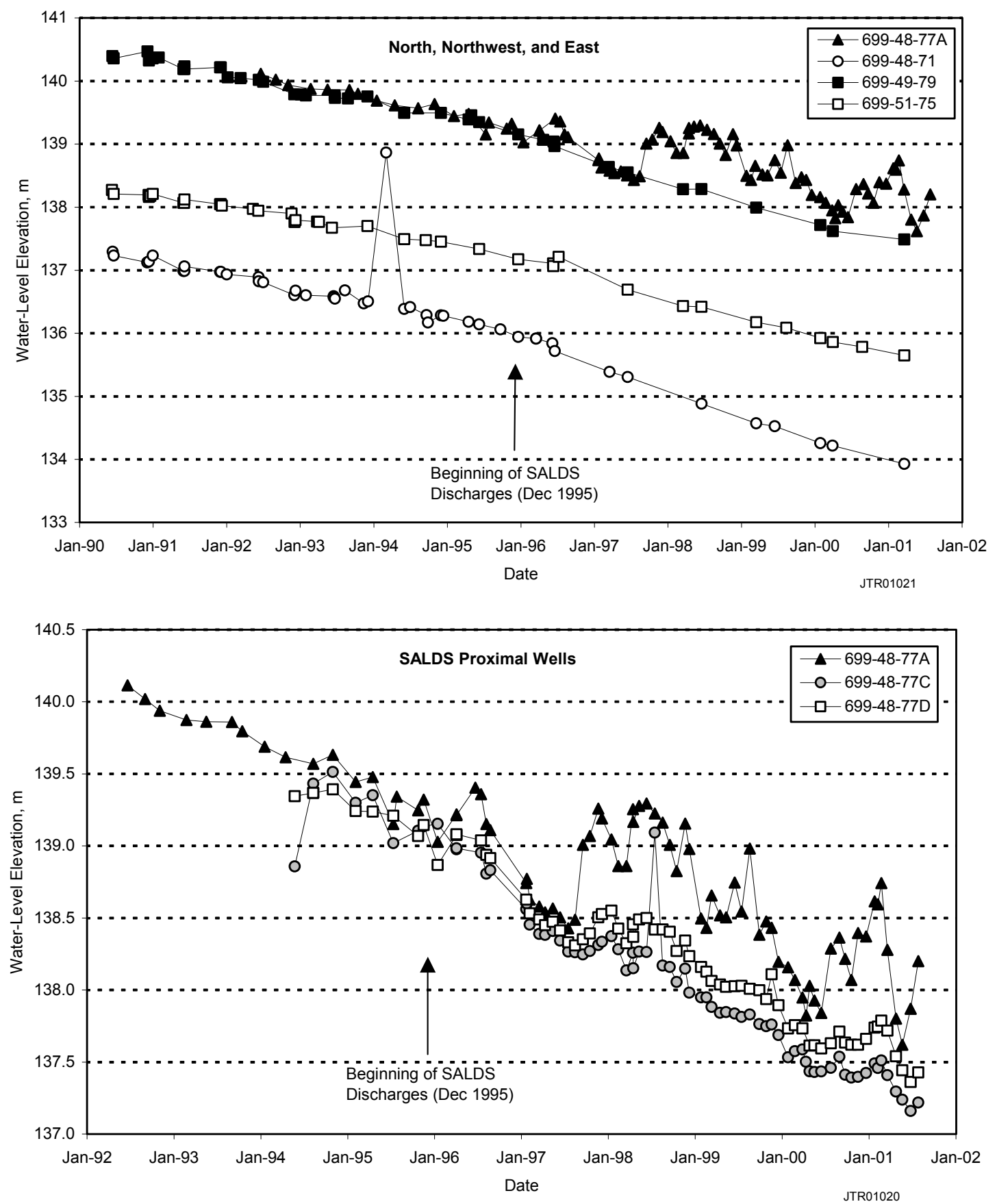

Figure 3. Hydrographs of Tritium-Tracking Wells North, Northwest, and East of the SALDS, Compared with Well 699-48-77A (top) and SALDS Proximal Wells (bottom). Well 699-48-77C is completed (screen) 20 m deeper within the aquifer than the other two proximal wells. 

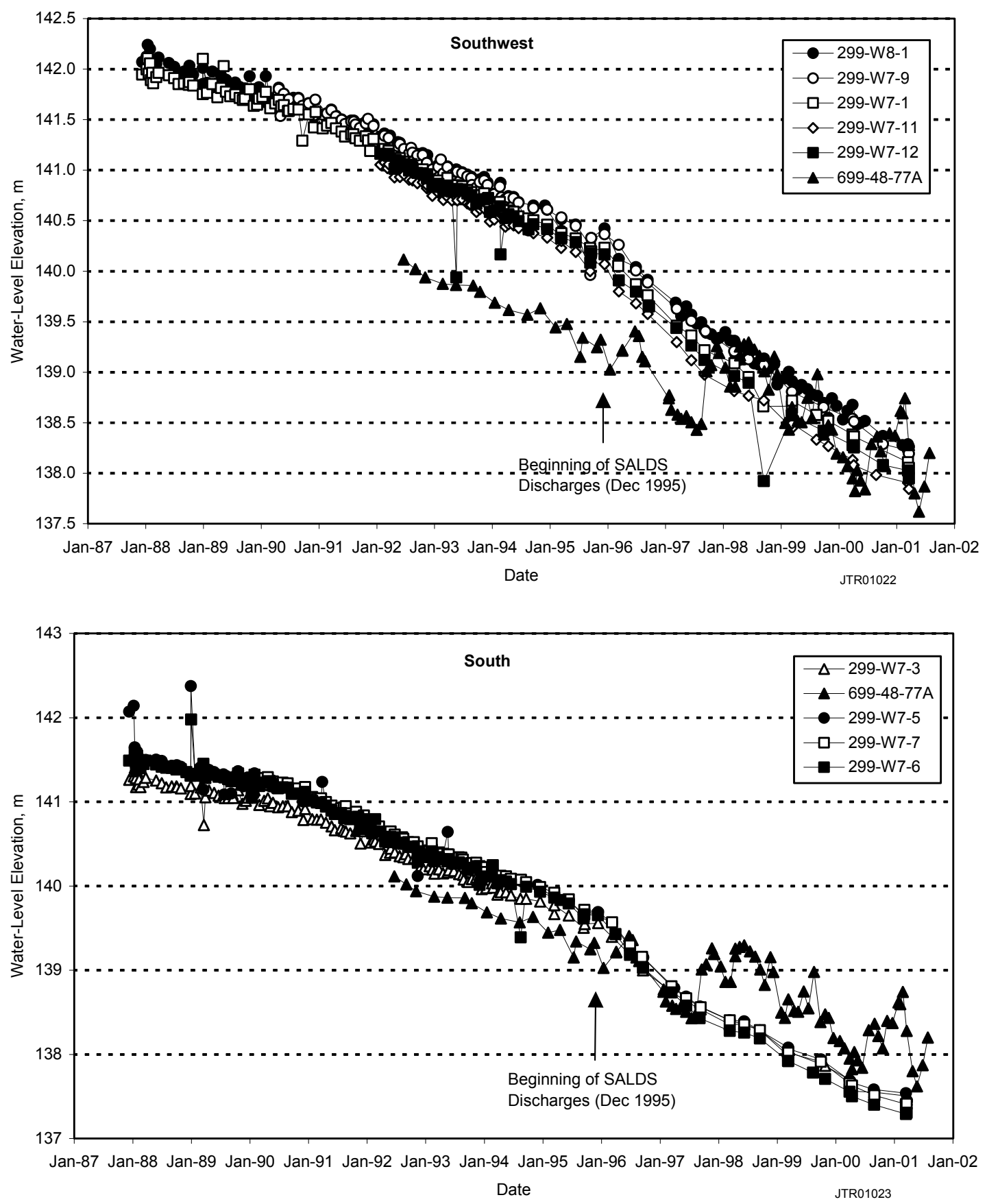

Figure 4. Hydrographs of Tritium-Tracking Wells Southwest (top) and South (bottom) of the SALDS Compared with Well 699-48-77A 

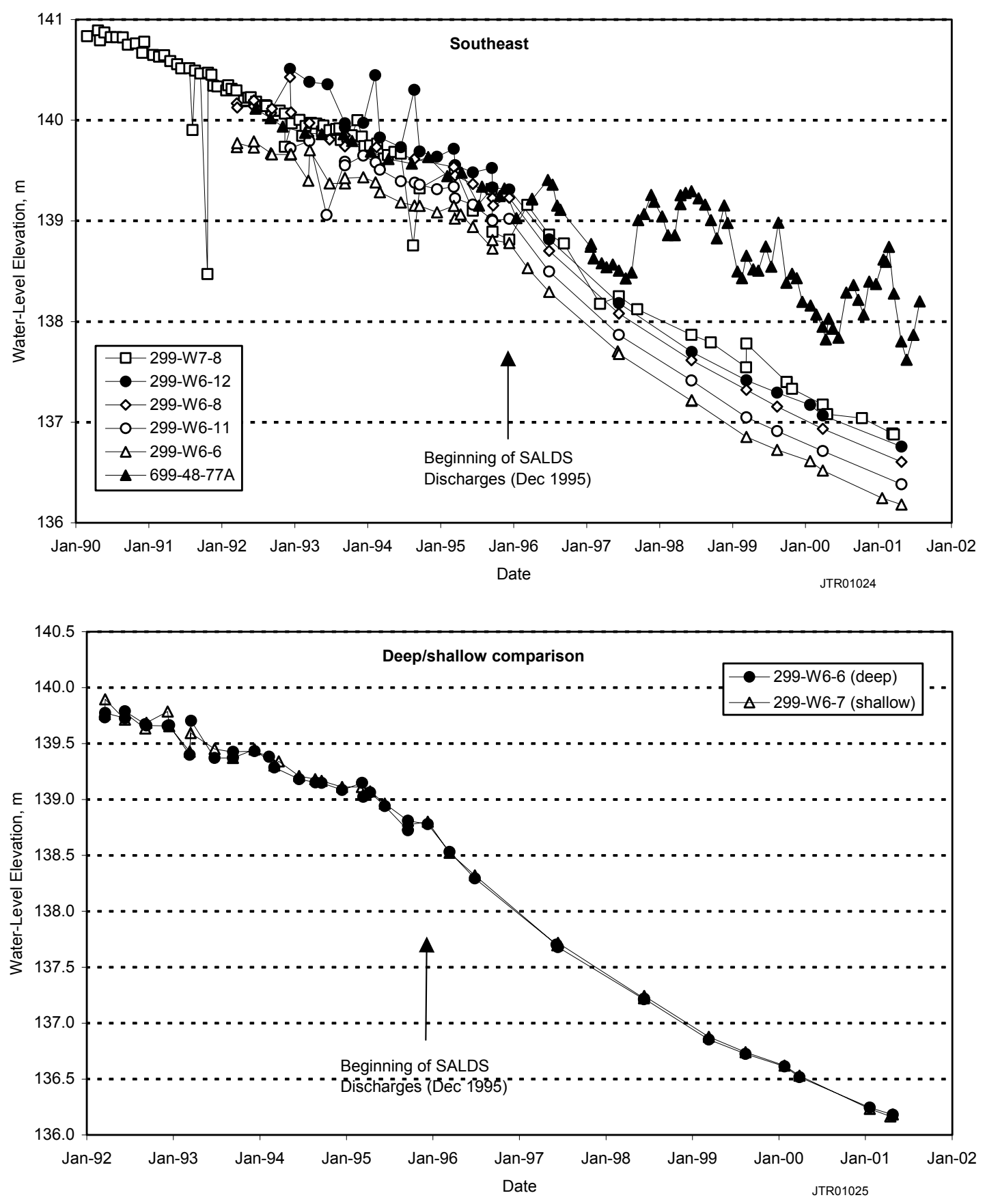

Figure 5. Hydrographs of Tritium-Tracking Wells Southeast of SALDS Compared with Well 699-48-77A (top) and Deep/Shallow Companion Wells (bottom). Well 299-W6-6 is completed approximately $49 \mathrm{~m}$ deeper in the aquifer than well 299-W6-7. 


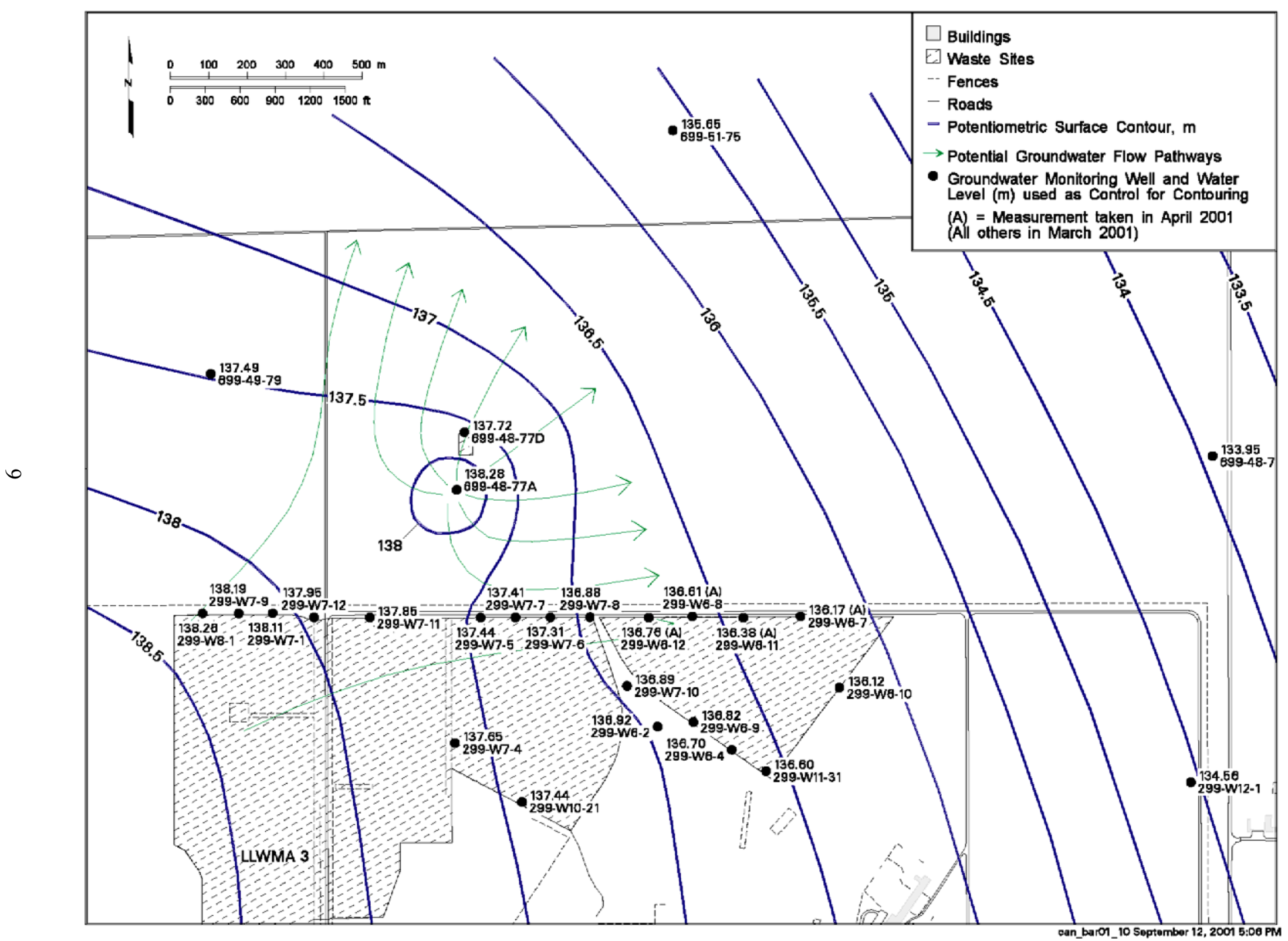

Figure 6. Water Table Map and Interpreted Groundwater Flow Directions in the SALDS Area for March/April 2001 


\subsection{Results of Groundwater Analyses for Tritium}

Results of tritium analyses in the SALDS tritium-tracking well network for FY 2001 are shown on Figure 7 and listed in Appendix A. Wells in the SALDS proximal network (699-48-77A, 699-48-77C, and 699-48-77D) have been affected by SALDS tritium discharges since 1996. Wells 299-W6-7, 299-W6-8, and 299-W6-11 continue to show the effects of the decaying tritium plume originating from the northeast portion of the 200 West Area.

Figure 8 illustrates the trends in tritium activities in the three SALDS proximal wells (see Figure 7 for location). Well 699-48-77A was first affected by discharges in July 1996. Although this well is farthest away from the facility of the three "proximal" SALDS wells, subsurface geologic features allowed the effluent to reach this well before any others (see Barnett et al. 1997; Barnett 2000a). This well produced a maximum tritium activity during FY 2001 of 670,000 pCi/L (February 2001), which is more than four times higher than the FY 2000 maximum. The reason for this increase is that significant tritium discharges to the SALDS resumed in September 2000. This followed a hiatus in tritium discharge since April 1999.

The maximum tritium result for well 699-48-77D in FY 2001 was 280,000 pCi/L (November 2000), which is down from a maximum of $420,000 \mathrm{pCi} / \mathrm{L}$ in FY 2000. Well 699-48-77D is nearest the SALDS, but showed tritium incursion only as recently as September 1997, about 18 months later than the more distant well 699-48-77A. The reason for this delay is related to the fact that the SALDS drainfield fills from the end of the facility (south end) farthest away from well 699-48-77D and the aforementioned geologic features beneath the SALDS. These two conditions shunt the subsurface flow of effluent away from well 699-48-77D before it reaches groundwater.

Well 699-48-77C is screened $\sim 20 \mathrm{~m}$ deeper in the aquifer than wells $699-48-77 \mathrm{~A}$ and $699-48-77 \mathrm{D}$. Because of its deeper position, tritium incursions from SALDS operation have been historically lower in activity and intermittent in this well until recently. During times of high discharge, the hydraulic head beneath the SALDS is increased, and effluent is forced deeper into the aquifer. The historical high tritium activity of 980,000 pCi/L was measured in well 699-48-77C in February 2001, indicating that the downward-moving SALDS effluent from earlier (prior to April 1999), tritium-rich discharges is still reaching this location in considerable strength. The trend shown in Figure 8, which indicates successively lower activities measured in April and July 2001, suggests that the maximum strength of the tritium plume from the early discharges may have reached this well, and activities are now declining.

A few wells along the border of the 200 West Area, generally southeast of the SALDS, have produced elevated values for tritium as a result of historical disposal practices in the 200 West Area. As shown in Figure 9, tritium activities in these wells have generally decreased or remained the same over the past several years. Well 299-W6-7 experienced a $~ 50 \%$ decline in activity between FY 2000 and FY 2001 measurements for tritium. This rate of decline is much more rapid than the historical rate. Well 299-W7-8 has also produced detectable tritium (as high as $800 \mathrm{pCi} / \mathrm{L}$ ) prior and subsequent to SALDS operation, but the overall trend in this well for tritium activity is downward. 
During FY 2000, it was speculated that results from wells 299-W7-3 and 299-W7-7 may have indicated the first arrival of tritium from the SALDS in this area (note departures in Figure 9; Barnett 2000b). Results of reanalysis of the samples and subsequent sampling now suggest that such speculation may be in error, and that results thus far provide no conclusive evidence of incursion of SALDS effluent in these wells.

Well 299-W7-5 has produced detectable tritium results sporadically since 1991 . Some of the detections from this well may be false because of large counting errors or actual detections of the decaying plume originating from the 200 West Area. The most recent tritium result from this well (July 2001) indicated activities below detection limits.

In the July 2001 sampling event, it was discovered that well 299-W7-6 no longer has sufficient water to produce a reliable sample by conventional means (pump). Other methods are currently being considered for retrieving a sample from this well for tritium analysis. Because the well is in a closely spaced array with other wells in this area, its loss would not be critical to the network.

Well 299-W8-1 is nearly $1 \mathrm{~km}$ away from the SALDS and has produced tritium results slightly above detection limits historically, even prior to SALDS operations. If these marginally detectable results are genuine, the source of tritium is from other 200 West Area operations.

Well 699-48-71, east of the SALDS, has historically (prior to SALDS operations) produced tritium activity results comparable to the FY 2001 result of $250 \mathrm{pCi} / \mathrm{L}$. Although this level of activity is near the method detection limit, it could be that this well is affected by the outer limbs of the tritium plume emanating from the 200 West Area (see tritium distribution map in Hartman et al. 2001). 


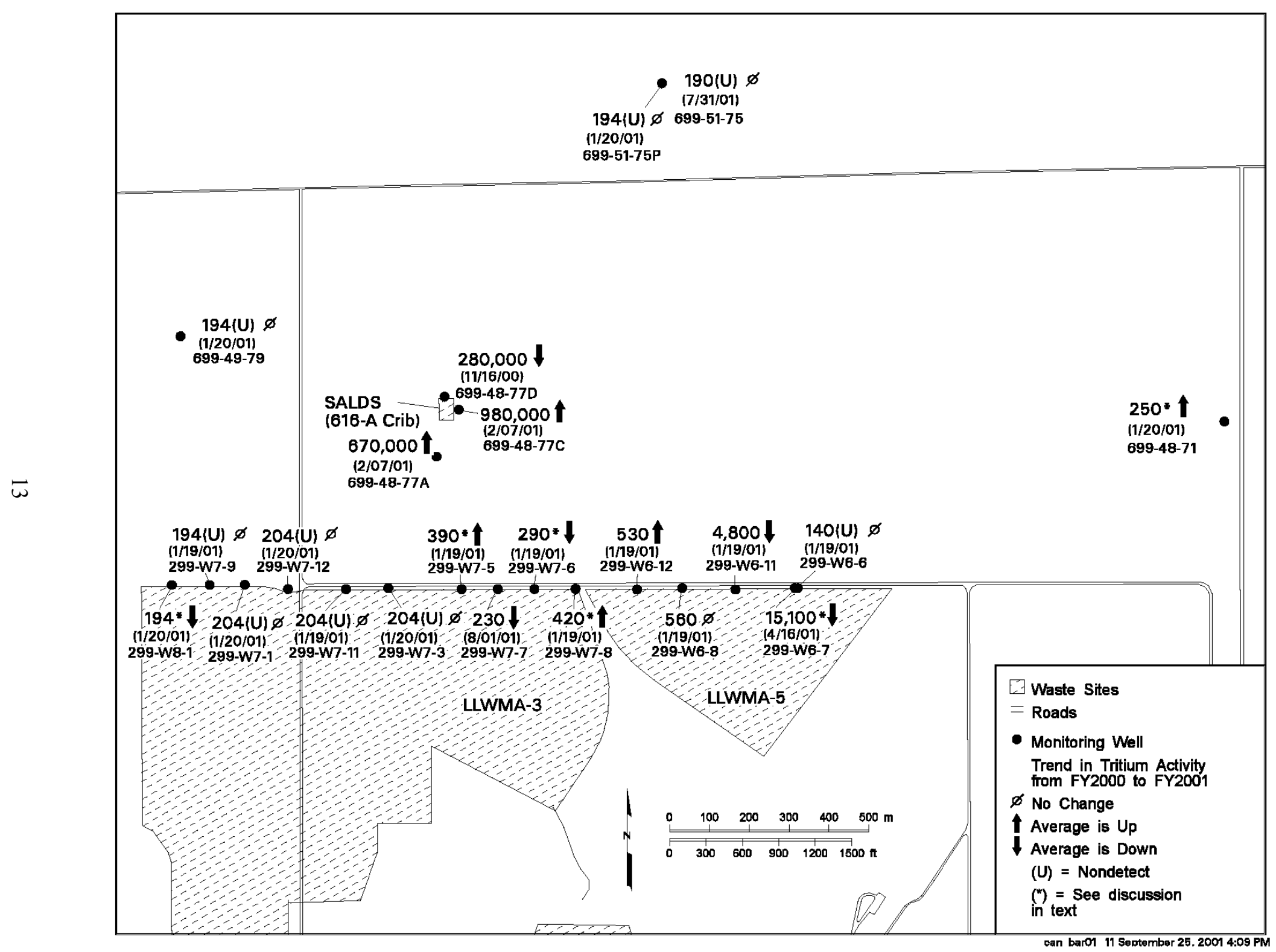

Figure 7. Maximum Tritium Activities in Groundwater for the SALDS Tritium-Tracking Network for FY 2001, Indicating (date of measurement) Change from FY 2000 


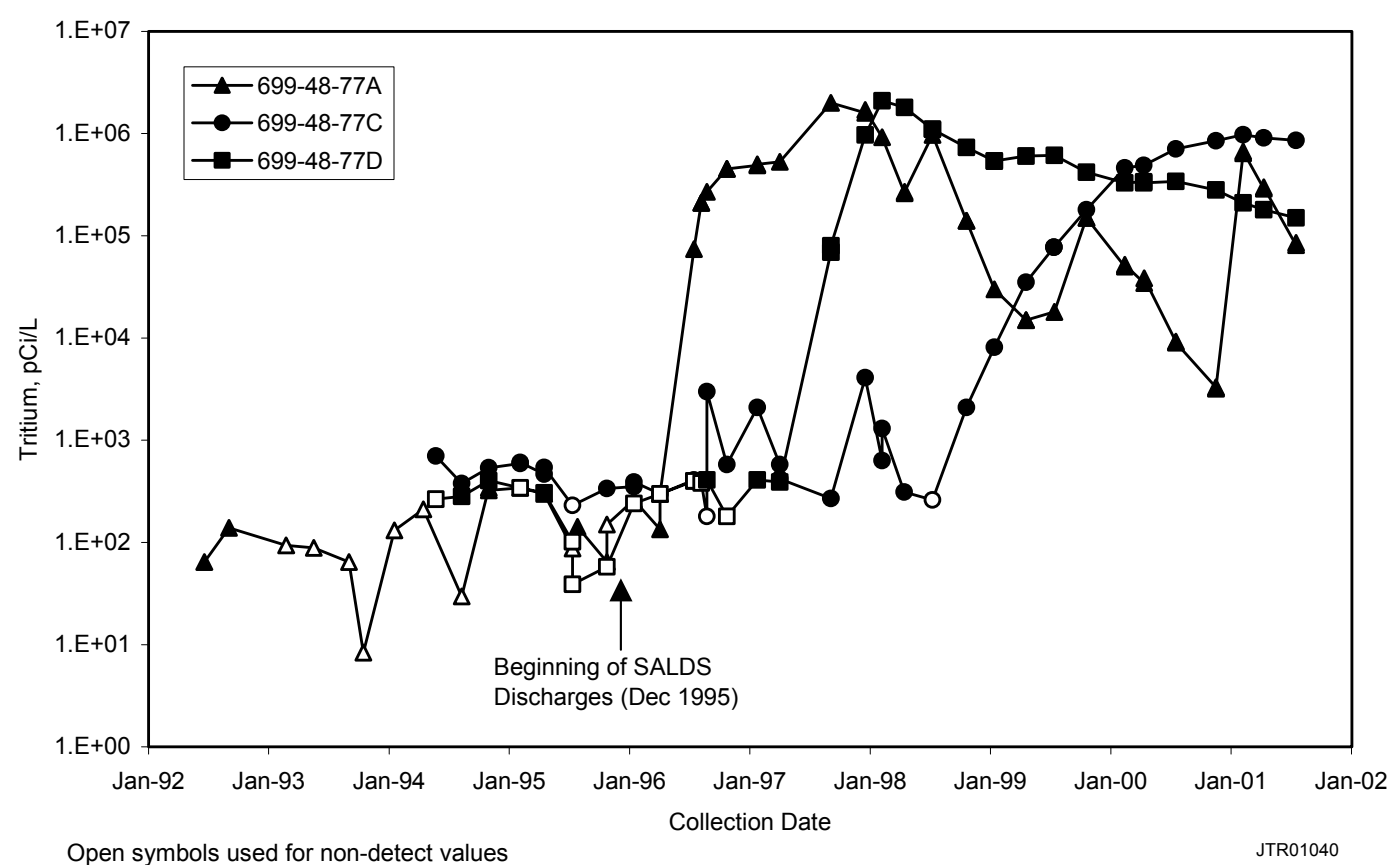

Figure 8. Tritium Activity Trends in SALDS Proximal Wells Through August 2001. Well $699-48-77 \mathrm{C}$ is completed $\sim 20 \mathrm{~m}$ deeper in the aquifer than wells 699-48-77A and 699-48-77D. 

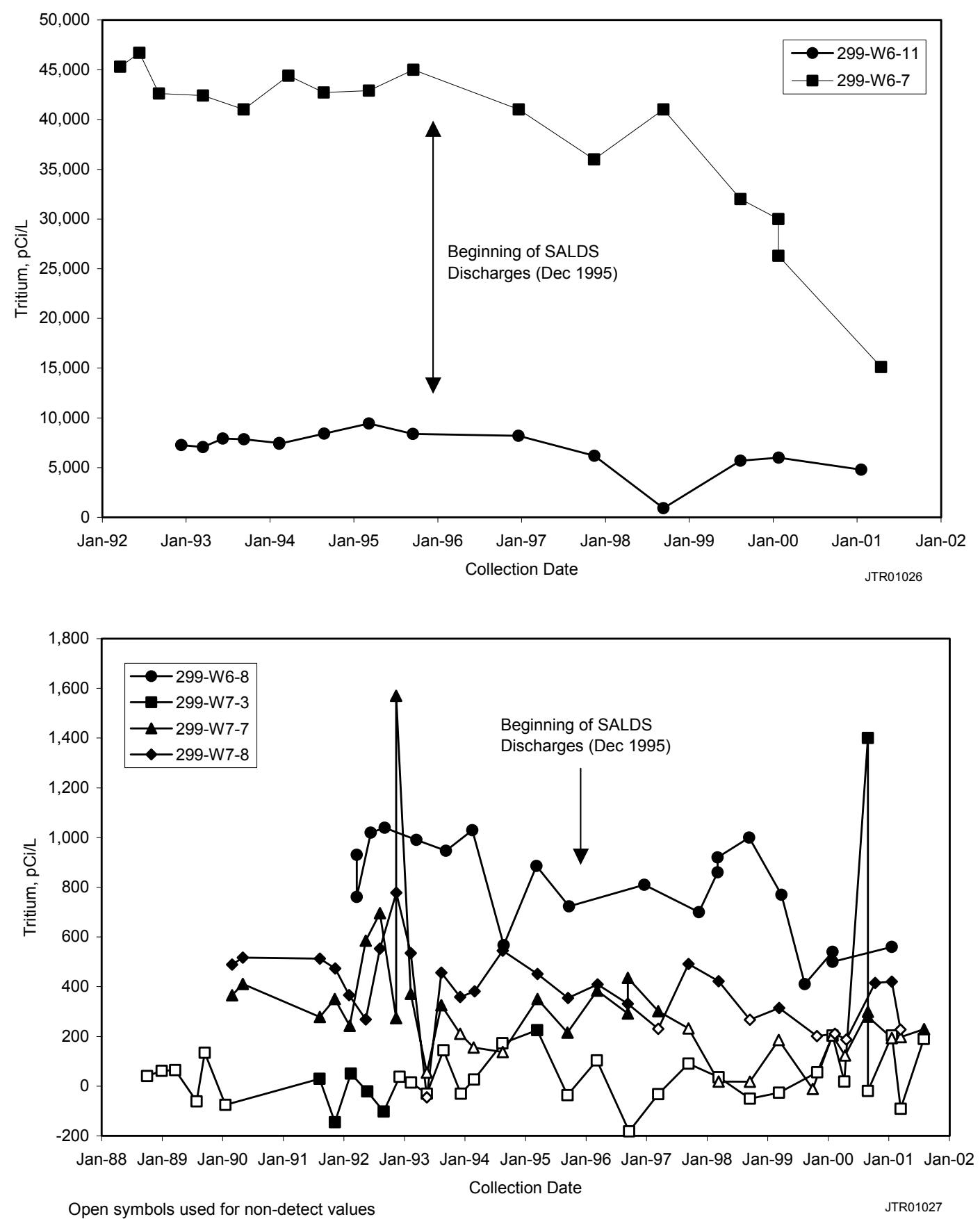

Figure 9. Tritium Activity Trends in Wells Southeast of the SALDS Showing Remnant Effects of the Tritium Plume from the 200 West Area and Recent Changes in Trends for Wells 299-W7-3 and 299-W7-7. The high value for well 299-W7-7 is suspected to be erroneous, with a duplicate on this date producing a result in line with the historic range. 


\subsection{Other Constituents in Groundwater}

In addition to tritium, groundwater from the SALDS proximal wells (699-48-77A, 699-48-77C, and 699-48-77D) is analyzed for a list of 15 constituents required by the State Waste Discharge Permit ST-4500 Special Condition S1 (A). Enforcement limits were set for most of these constituents [acetone, benzene, cadmium (total), chloroform, copper (total), lead (total), mercury (total), $\mathrm{pH}$, sulfate, tetrahydrofuran, total dissolved solids (TDS)]. Gross alpha, gross beta, strontium-90, and tritium are not assigned enforcement limits, but are monitored and reported. Additional parameters, such as alkalinity and dissolved oxygen, are sought for determination of general groundwater characteristics and verifying the quality of analytical results. Maximum concentrations for these constituents, and the corresponding sample months for FY 2001, are listed in Table 1.

Of the 11 constituents with permit limits, all were below the ST-4500 enforcement limits for groundwater during FY 2001 ${ }^{1}$. As in FY 2000, acetone, benzene, chloroform, and tetrahydrofuran results were reported below detection limits in all three wells for all of FY 2001.

Total concentrations for the metals were all within groundwater permit limits for all results during FY 2001. Mercury was above detection in wells 699-48-77A and 699-48-77C during FY 2001, but duplicate results for this element on the same sample dates, and subsequent sample results for both wells are qualified " $u$ " (non-detect). Well 699-48-77D produced one anomalous result for copper (still below enforcement levels) of $51.5 \mu \mathrm{g} / \mathrm{L}$. However, this result is accompanied by a duplicate result of only $0.71 \mu \mathrm{g} / \mathrm{L}$, which is within the range of historical concentrations. All results for lead and cadmium were below detection during FY 2001.

The annual laboratory measurements of $\mathrm{pH}$ performed in February 2001 are in general agreement with the ranges of field $\mathrm{pH}$ values measured during FY 2001. No trends are evident for this parameter since monitoring of SALDS wells began in 1992-1994.

FY 2001 maxima for gross alpha and gross beta results in SALDS wells remain within published Hanford Site background (Johnson 1993; DOE-RL 1997) ranges for these two indicators. The highest gross alpha result for FY 2001 of 1.7 pCi/L was recorded for well 699-48-77C in November 2000. Gross beta was highest in well 699-48-77A, with a maximum result of $3.0 \mathrm{pCi} / \mathrm{L}$. These results are lower than maximum results for both indicators in FY 2000.

Strontium-90 is the only radionuclide (other than tritium) that is specifically monitored at the SALDS, and was reported above detection in all three proximal wells during FY 2001, but is down in activity from FY 2000. Historically, results for strontium-90 have been subject to high counting errors. During FY 2001, several split samples from SALDS wells were analyzed for this radionuclide independently from the routine laboratory. All of the results from these independent analyses were below

\footnotetext{
${ }^{1}$ Period reported is October 1, 2000 through August 31, 2001.
} 
detection. Thus, it seems unlikely that strontium-90 is actually present in detectable activities (using routine methods of detection) in groundwater beneath the SALDS.

Coincident with the first detection of elevated tritium in late 1996, concentrations of sulfate and a few other parameters were also found to have increased in groundwater from well 699-48-77A. These occurrences were interpreted to be a result of the dilute (clean water) effluent from SALDS dissolving soluble mineral species (such as gypsum) in the vadose zone during infiltration (Thornton 1997; Barnett et al. 1997). More recently, wells 699-48-77C and 699-48-77D have shown similar incursions of these constituents. Figures 10 through 12 show the trends for some of the parameters in the SALDS wells that best reflect this phenomenon; e.g., sulfate, conductivity, and TDS. Trends for these parameters in well 299-W8-1 are shown for comparison. Other species, such as calcium and sodium, show a more subdued response during the same time period. The trends are most pronounced in wells 699-48-77A and 699-48$77 \mathrm{D}$ because these wells are screened at the water table. These six parameters have trended downward for the past 3 years in wells 699-48-77A and 699-48-77D, and are now below initial background concentrations in these two wells. Well $699-48-77 \mathrm{C}$ is screened $\sim 20 \mathrm{~m}$ below the water table. The effects of SALDS discharges in this well are thus delayed and retarded with respect to the two shallow wells. Concentrations that are more characteristic of the dilute effluent from the SALDS have replaced the natural levels to a minor degree. Occasional "spikes" of these and related parameters may be expected to occur sporadically at any of the SALDS proximal wells, but at lower levels of concentration than in the original occurrences. 
Table 1. Maximum Concentrations of Constituents in Groundwater and Corresponding Sample Month, SALDS, FY 2001

\begin{tabular}{|c|c|c|c|}
\hline Constituent (permit limit) & Well 699-48-77A & Well 699-48-77C & Well 699-48-77D \\
\hline Acetone (160) & (u) & (u) & (u) \\
\hline Benzene (5) & (u) & (u) & (u) \\
\hline Cadmium, total (10) & (u) & (u) & (u) \\
\hline Chloroform (6.2) & (u) & $(\mathrm{u})$ & (u) \\
\hline Copper, total (70) & 3.51-Apr 2001 & $1.12-\mathrm{Jul} 2001$ & $51.5^{(\mathrm{a})}$ \\
\hline Lead, total (50) & (u) & (u) & (u) \\
\hline Mercury, total (2) & $0.191-\operatorname{Nov} 2000^{(a)}$ & $0.171-\operatorname{Nov} 2000^{(a)}$ & (u) \\
\hline $\begin{array}{l}\text { Laboratory } \mathrm{pH}, \mathrm{pH} \text { units } \\
(6.5-8.5)\end{array}$ & $8.01-8.03^{(b)}$ & $7.89^{(\mathrm{c})}$ & $8.01^{(\mathrm{c})}$ \\
\hline $\begin{array}{l}\text { Field } \mathrm{pH}, \mathrm{pH} \text { units }{ }^{(\mathrm{b})} \\
(6.5-8.5)\end{array}$ & $8.01-8.26$ & $7.68-7.97$ & $8.01-8.21$ \\
\hline Sulfate $(250,000)$ & 2,042-Feb 2001 & 34,320 -Nov 2000 & 10,810 -Nov 2000 \\
\hline Tetrahydrofuran (100) & (u) & (u) & (u) \\
\hline $\begin{array}{l}\text { Total Dissolved Solids } \\
(500,000)\end{array}$ & $136,000-$ Jul 2001 & $219,000-$ Nov 2000 & 164,000 - Nov 2000 \\
\hline Gross Alpha, pCi/L ${ }^{(\mathrm{d})}$ & (u) & $1.5-\mathrm{Nov} 2000$ & $1.7-$ Nov 2000 \\
\hline Gross Beta, $\mathrm{pCi} / \mathrm{L}^{(\mathrm{d})}$ & $3.0-\mathrm{Jul} 2001$ & $2.3-\mathrm{Feb} 2001$ & $1.8-\mathrm{Jul} 2001$ \\
\hline Strontium-90, $\mathrm{pCi} / \mathrm{L}^{(\mathrm{d})}$ & $3.1-\mathrm{Jul} 2001^{(\mathrm{a})}$ & $2.7-\operatorname{Nov} 2000^{(a)}$ & 1.0 -Apr $2001^{(\mathrm{a})}$ \\
\hline Tritium, $\mathrm{pCi} / \mathrm{L}^{(\mathrm{b})}$ & $670,000-F e b 2001$ & $980,000-F e b 2001$ & $280,000-$ Nov 2000 \\
\hline Alkalinity, mg/L ${ }^{(\mathrm{e})}$ & 75 & 120 & 110 \\
\hline $\begin{array}{l}\text { Field Conductivity, } \\
\mu \mathrm{S} / \mathrm{cm}^{(\mathrm{e})}\end{array}$ & 158 & 334 & 257 \\
\hline Dissolved Oxygen $^{(\mathrm{e})}$ & 9,220 & 12,090 & 9,700 \\
\hline Field Temperature, ${ }^{\circ} \mathrm{C}^{(\mathrm{e}, \mathrm{b})}$ & $20.50-26.10$ & $16.50-18.90$ & $16.20-19.50$ \\
\hline Turbidity, NTU ${ }^{(\mathrm{e}, \mathrm{b})}$ & $1.52-8.04$ & $1.07-36.10^{(\mathrm{a})}$ & $3.90-15.00$ \\
\hline $\begin{array}{l}\text { Notes: } \\
\text { 1. All concentrations in } \\
\text { 2. "(u)" = not detected. } \\
\text { (a) Anomalous or suspect } \\
\text { (b) Entire range of reading } \\
\text { (c) Only result for this par } \\
\text { (d) Constituent is not assig } \\
\text { (e) Constituent is sought } \mathrm{f} \\
\text { to permit conditions } \\
\end{array}$ & $\begin{array}{l}\text { L unless noted. } \\
\text { foding-see text for disc } \\
\text { for FY } 2001 \text { (October } 1 \\
\text { meter. } \\
\text { ed an enforcement limit } \\
\text { evaluation of groundw } \\
\end{array}$ & $\begin{array}{l}\text { ion. } \\
00 \text { through August 31, } \\
\text { t is subject to routine } n \\
\text { character and analytica }\end{array}$ & $\begin{array}{l}001) \text {. } \\
\text { qualitoring and reporting. } \\
\end{array}$ \\
\hline
\end{tabular}




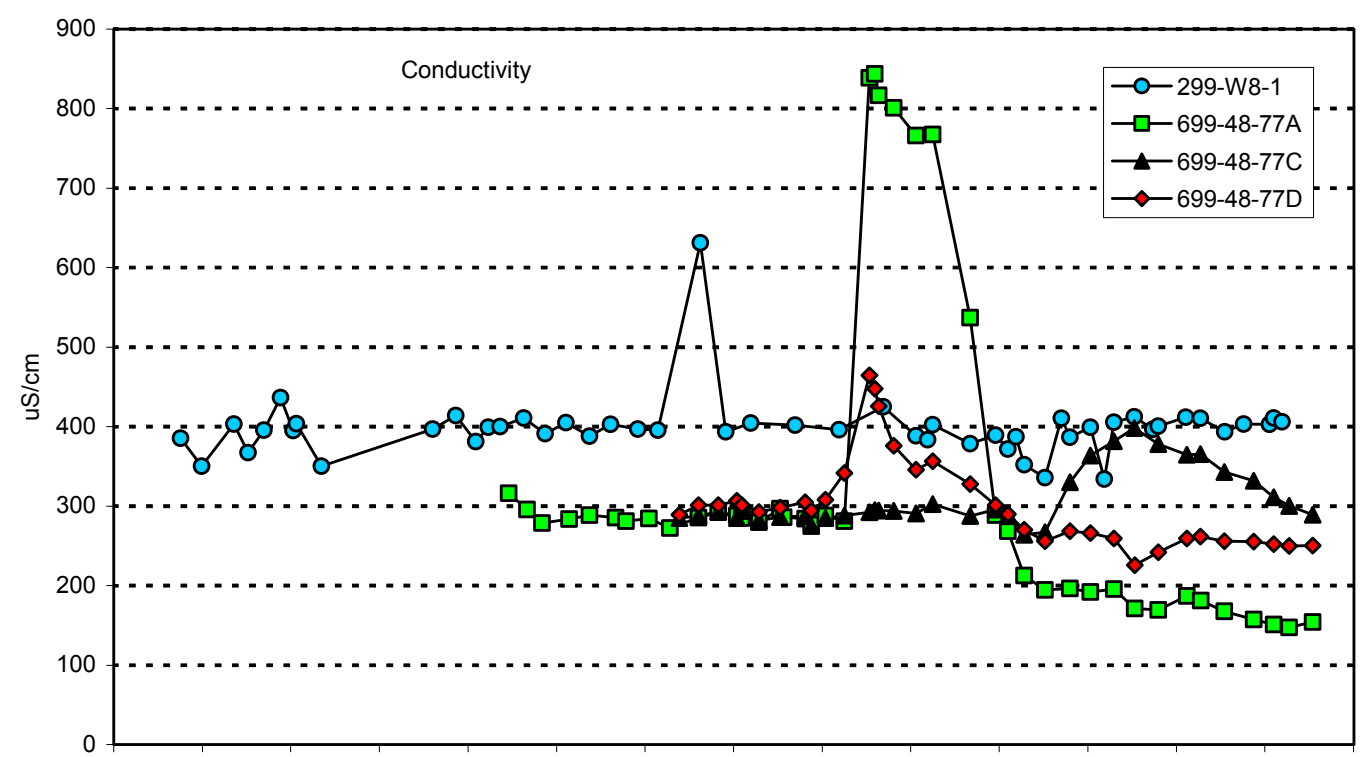

Jan-88 Jan-89 Jan-90 Jan-91 Jan-92 Jan-93 Jan-94 Jan-95 Jan-96 Jan-97 Jan-98 Jan-99 Jan-00 Jan-01 Jan-02 Collection Date

JTR01032

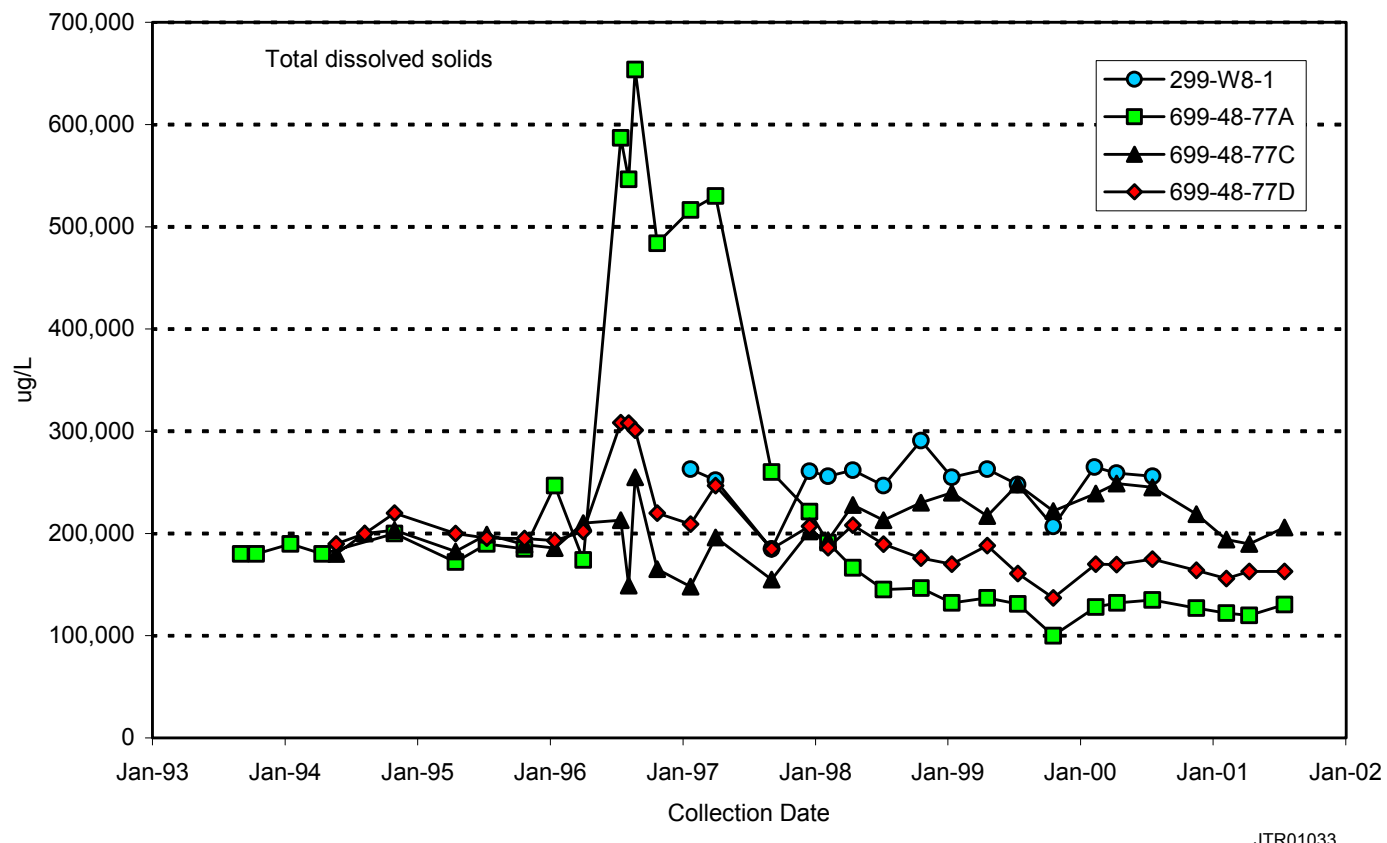

Figure 10. Trend Plots for Conductivity and Total Dissolved Solids in SALDS Proximal Wells and Well 299-W8-1 


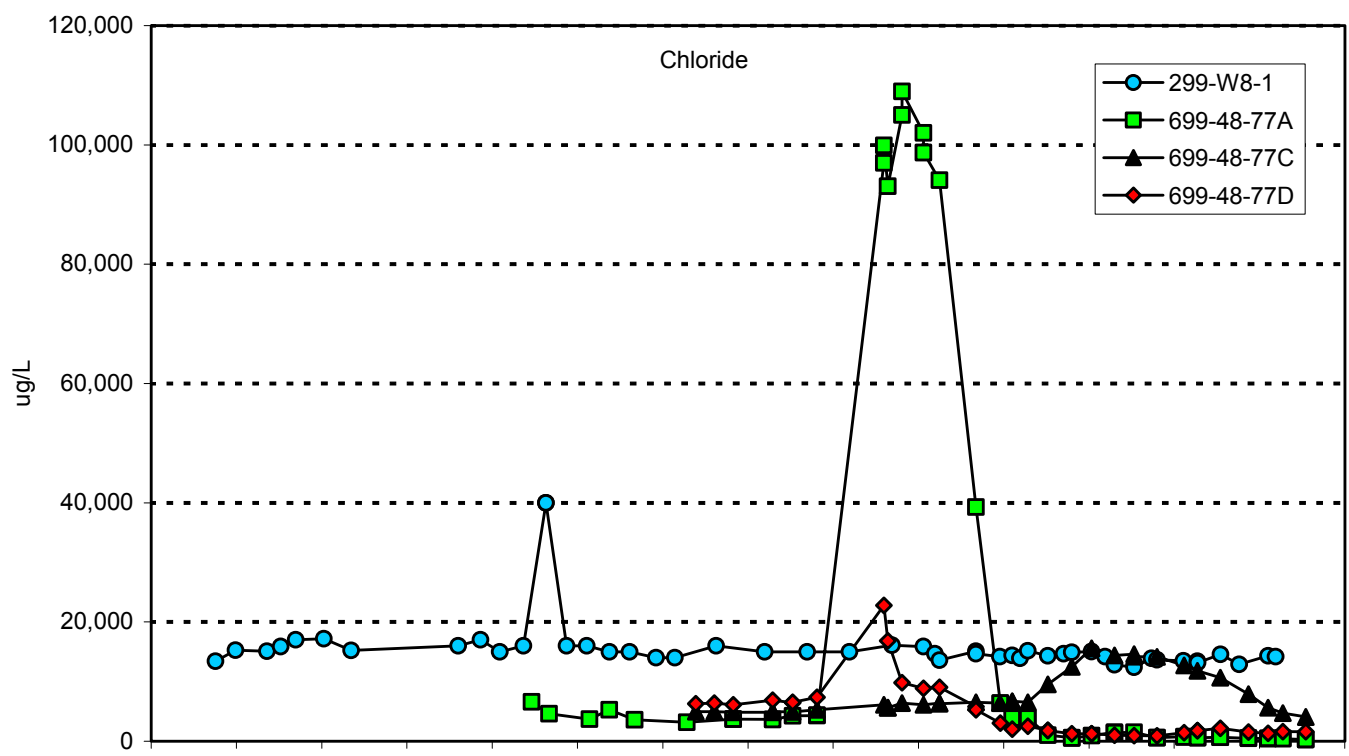

Jan-88 Jan-89 Jan-90 Jan-91 Jan-92 Jan-93 Jan-94 Jan-95 Jan-96 Jan-97 Jan-98 Jan-99 Jan-00 Jan-01 Jan-02 Collection Date

JTR01030

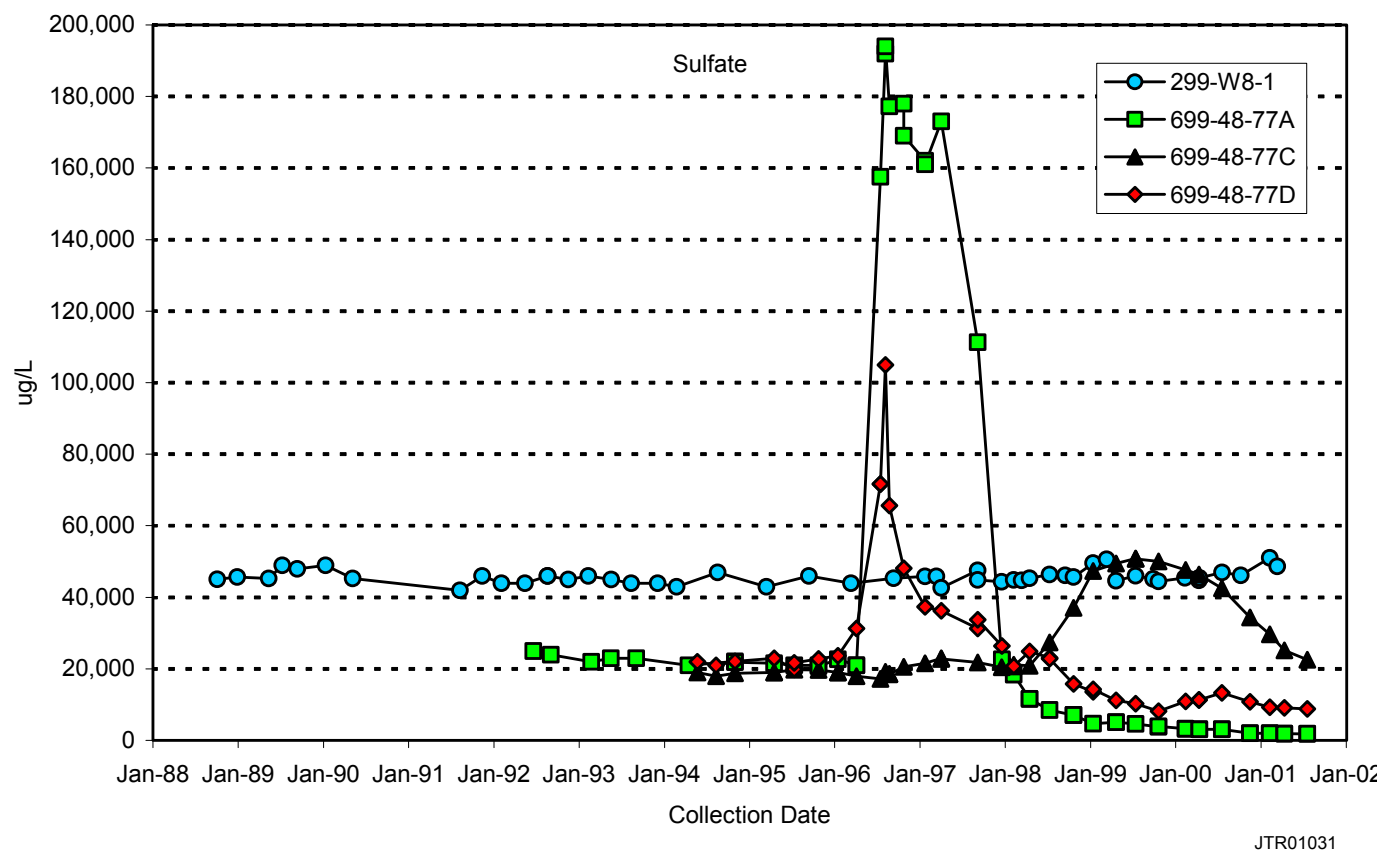

Figure 11. Trend Plots for Chloride and Sulfate in SALDS Proximal Wells and Well 299-W8-1 


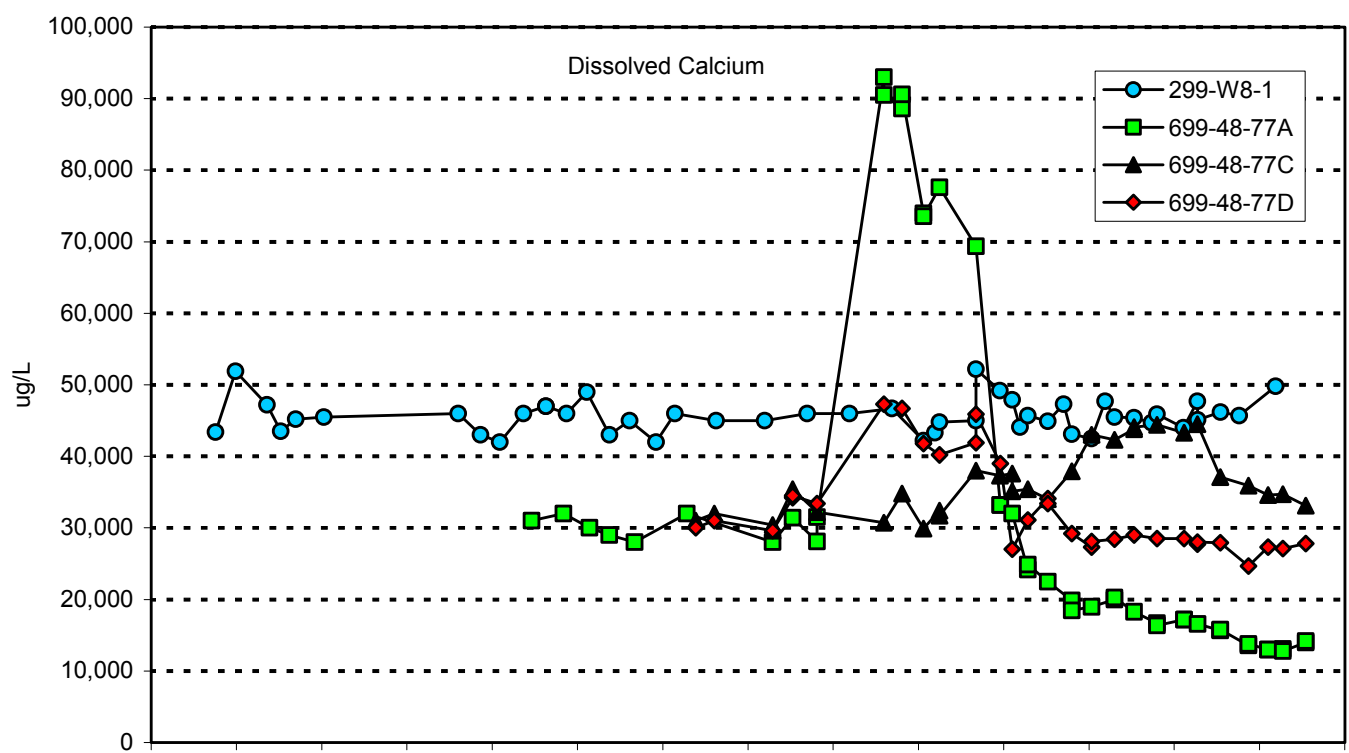

Jan-88 Jan-89 Jan-90 Jan-91 Jan-92 Jan-93 Jan-94 Jan-95 Jan-96 Jan-97 Jan-98 Jan-99 Jan-00 Jan-01 Jan-02 Collection Date

JTR01028

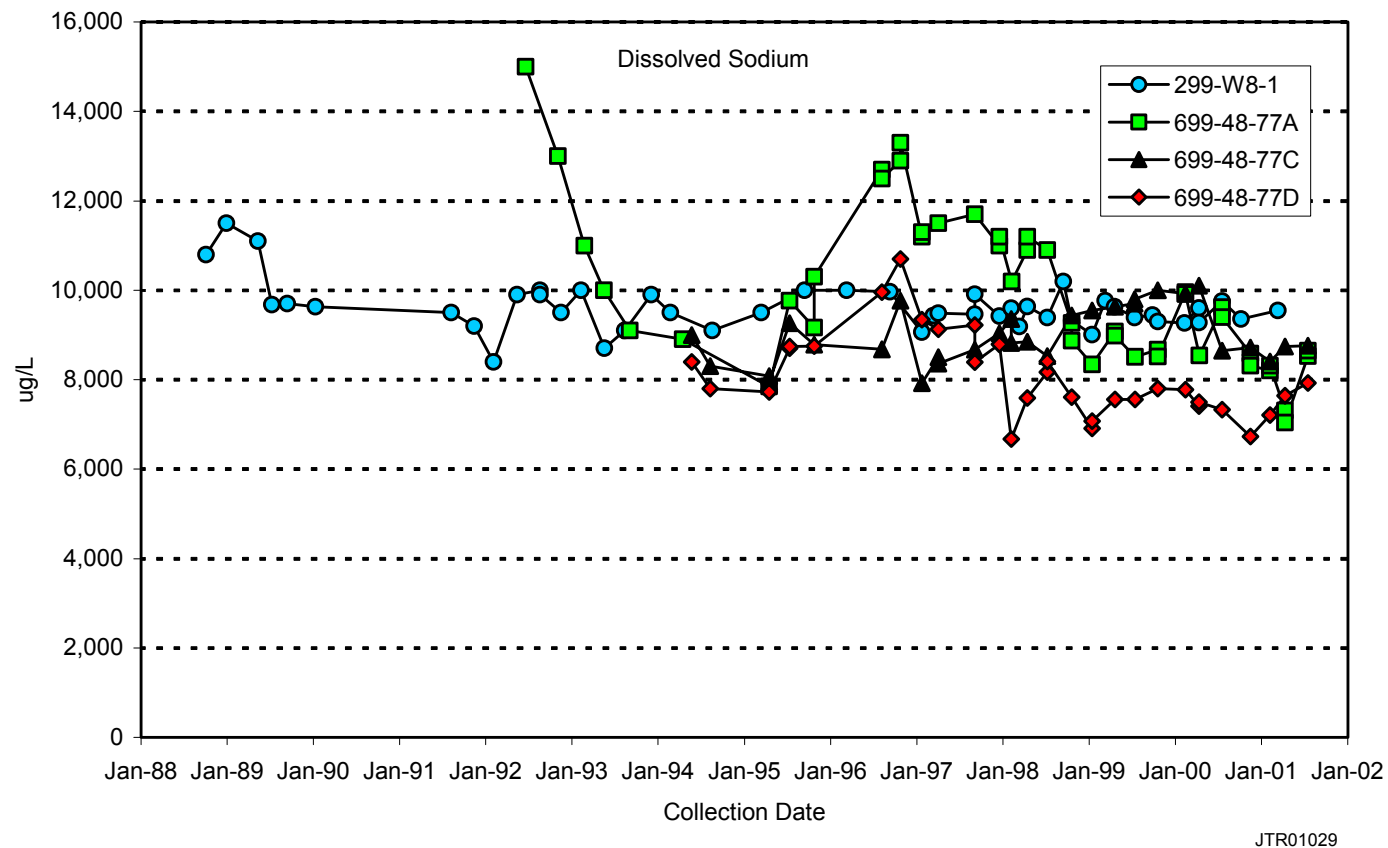

Figure 12. Trend Plots for Dissolved Calcium and Dissolved Sodium for SALDS Proximal Wells and Well 299-W8-1 


\subsection{Discussion and Recommendations}

Water levels in SALDS wells continue to reflect the influence of the groundwater mounding in the immediate vicinity of SALDS from continued effluent disposal at the facility. This effect is superimposed upon the general decline in the water table in the 200 West Area from the discontinuation of disposal practices several years ago.

Based on the latest arrival of elevated tritium in well 699-48-77A (between November 2000 and February 2001) and the timing of resumed tritium discharges to the SALDS (September 2000), travel time from the facility to the well is from 74 to 129 days. Actual travel time to groundwater from the facility will be an undetermined length of time less than the maximum of this range, because the effluent is thought to enter groundwater somewhere between the SALDS and well 699-48-77A (Barnett 2000a).

Trends in concentrations of anions, certain metals, and indicators (see Section 4.0) in groundwater beneath the SALDS indicate an initial leaching of natural soil salts, followed by a recent dilutive event resulting in depression of concentrations below background in wells 699-48-77A and 699-48-77D, especially for conductivity, chloride, and sulfate. Well 699-48-77C is still reflecting the early part of this sequence - several of these parameters have begun to decline, but are not below SALDS pre-operational levels. Because of its position deeper in the aquifer, the effects of these dissolved components are more subdued than concentrations in the wells completed at the water table. In the future, fluctuations in concentrations of these constituents may occur as volumes and/or duration of discharge events to the SALDS vary. As long as cessation in SALDS discharges do not occur, effluent in the vadose zone will not reestablish equilibrium with the aquifer solids, so the dilute groundwater signature will be sustained. If SALDS operations were to cease for an extended period, effluent draining through the vadose zone may begin to partially equilibrate geochemically with the soil materials. Subsequent restarts may then produce another "spike" of dissolved ions, though not as concentrated as the first arrival of SALDS effluent at the water table in well 699-48-77A during 1996 and 1997.

Because of the continuation of elevated hydraulic head in the vicinity of the SALDS, wells south and southeast, and intermittently those southwest of SALDS, are hydraulically downgradient of the facility (see Figures 3 through 5). Consequently, it is advisable to continue monitoring these wells for the arrival of tritium. Monitoring in these locations will provide accurate determination of the southern bounds of the SALDS-generated tritium plume, provide estimates of travel time for model comparisons, and help preserve the distinction between this plume and the older 200 West tritium plume farther east.

Some wells in the SALDS tritium-tracking and monitoring network may eventually become unserviceable as groundwater levels continue declining in the vicinity of the 200 West Area. Hence, it may become necessary to consider the installation of additional wells as replacements or in new locations.

Application of a revised numerical groundwater model will occur during the current permit cycle ending in CY 2005. In addition to predicting tritium movement, the model will assist in determining if

additional wells are needed and the appropriate locations for installation. Quantities of tritium discharged 
to the SALDS thus far are less than one-half of those assumed in the model. The result is that tritium has apparently not traveled as far as predicted from the SALDS in detectable quantities. 


\subsection{References}

Barnett, D. B. 2000a. Groundwater Monitoring and Tritium-Tracking Plan for the 200 Area StateApproved Land Disposal Site. PNNL-13121, Pacific Northwest National Laboratory, Richland, Washington.

Barnett, D. B. 2000b. Results of Tritium Tracking and Groundwater Monitoring at the Hanford Site 200 Area State-Approved Land Disposal Site-Fiscal Year 2000. PNNL-13329, Pacific Northwest National Laboratory, Richland, Washington.

Barnett, D. B., M. P. Bergeron, C. R. Cole, M. D. Freshley, and S. K. Wurstner. 1997. Tritium Monitoring in Groundwater and Evaluation of Model Predictions for the Hanford Site 200 Area Effluent Treatment Facility. PNNL-11665, Pacific Northwest National Laboratory, Richland, Washington.

DOE-RL. 1997. Hanford Site Background: Part 3, Groundwater Background. DOE/RL-96-61, U.S. Department of Energy, Richland Operations Office, Richland, Washington.

Hartman, M. J., L. F. Morasch, and W. D. Webber (eds.). 2001. Hanford Site Groundwater Monitoring for Fiscal Year 2000. PNNL-13404, Pacific Northwest National Laboratory, Richland, Washington.

Johnson, V. G. 1993. Westinghouse Hanford Company Operational Groundwater Status Report, 1990-1992. WHC-EP-0595, Westinghouse Hanford Company, Richland, Washington.

Thornton, E. C. 1997. Origin of Increased Sulfate in Groundwater at the ETF Disposal Site.

PNNL-11633, Pacific Northwest National Laboratory, Richland, Washington. 


\section{Appendix A}

\section{SALDS Tritium Results in Groundwater for FY 2001}


Table A.1. SALDS Tritium Results During FY 2001

\begin{tabular}{|c|c|c|c|c|}
\hline Well Number & $\begin{array}{c}\text { Date } \\
\text { Sampled } \\
\end{array}$ & Result, $\mathrm{pCi} / \mathrm{L}$ & Qualifier & Comments (change from FY 2000) \\
\hline 299-W6-11 & $01 / 19 / 01$ & $4,800.00$ & & (down) \\
\hline 299-W6-12 & $01 / 19 / 01$ & 530 & & (up slightly) \\
\hline 299-W6-6 & $01 / 19 / 01$ & 140 & $\mathrm{U}$ & (no change) \\
\hline 299-W6-7 & 04/16/01 & 15,100 & & $($ down $50 \%)$ \\
\hline 299-W6-8 & $01 / 19 / 01$ & 560 & & (no change) \\
\hline 299-W7-1 & $01 / 20 / 01$ & 204 & $\mathrm{U}$ & \\
\hline 299-W7-11 & $01 / 19 / 01$ & 204 & $\mathrm{U}$ & (no change) \\
\hline 299-W7-11 & 08/01/01 & 190 & $\mathrm{U}$ & \\
\hline 299-W7-11 & 08/01/01 & 190 & $\mathrm{U}$ & Duplicate \\
\hline 299-W7-12 & $01 / 20 / 01$ & 204 & $\mathrm{U}$ & \\
\hline 299-W7-3 & $01 / 20 / 01$ & 204 & $\mathrm{U}$ & (no change) \\
\hline 299-W7-3 & 03/13/01 & -91.6 & $\mathrm{U}$ & \\
\hline 299-W7-3 & $07 / 31 / 01$ & 190 & $\mathrm{U}$ & \\
\hline $299-W 7-5$ & $01 / 19 / 01$ & 390 & & (up slightly, but within trend-see subsequent results) \\
\hline 299-W7-5 & $07 / 31 / 01$ & 190 & $\mathrm{U}$ & \\
\hline $299-W 7-6$ & $01 / 19 / 01$ & 290 & & July sample not collected due to drying of well \\
\hline 299-W7-7 & $01 / 19 / 01$ & 194 & $\mathrm{U}$ & \\
\hline 299-W7-7 & $03 / 14 / 01$ & 198 & $\mathrm{U}$ & \\
\hline 299-W7-7 & $08 / 01 / 01$ & 230 & & (down) \\
\hline 299-W7-8 & $01 / 19 / 01$ & 420 & & (up slightly) \\
\hline 299-W7-9 & $01 / 19 / 01$ & 194 & $\mathrm{U}$ & \\
\hline 299-W8-1 & $01 / 20 / 01$ & 194 & $\mathrm{U}$ & \\
\hline $699-48-71$ & $01 / 20 / 01$ & 194 & $\mathrm{U}$ & \\
\hline $699-48-71$ & $01 / 20 / 01$ & 250 & & Duplicate \\
\hline 699-48-77A & $11 / 16 / 00$ & $3,300.00$ & & \\
\hline 699-48-77A & $11 / 16 / 00$ & $3,200.00$ & & Duplicate \\
\hline $699-48-77 \mathrm{~A}$ & $02 / 07 / 01$ & $640,000.00$ & & Duplicate \\
\hline 699-48-77A & $02 / 07 / 01$ & $670,000.00$ & & (up significantly) \\
\hline 699-48-77A & $04 / 11 / 01$ & $290,000.00$ & & \\
\hline 699-48-77A & $04 / 11 / 01$ & $300,000.00$ & & Duplicate \\
\hline 699-48-77A & $07 / 18 / 01$ & $81,000.00$ & & \\
\hline 699-48-77A & $07 / 18 / 01$ & $85,000.00$ & & Duplicate \\
\hline $699-48-77 \mathrm{C}$ & $11 / 16 / 00$ & $850,000.00$ & & \\
\hline 699-48-77C & $02 / 07 / 01$ & $980,000.00$ & & (up) \\
\hline $699-48-77 \mathrm{C}$ & $04 / 11 / 01$ & $910,00.00$ & & \\
\hline 699-48-77C & $07 / 18 / 01$ & $860,000.00$ & & \\
\hline 699-48-77D & $11 / 16 / 00$ & $280,000.00$ & & (down) \\
\hline 699-48-77D & $02 / 07 / 01$ & $210,000.00$ & & \\
\hline 699-48-77D & 04/11/01 & $180,000.00$ & & \\
\hline 699-48-77D & 07/18/01 & $150,000.00$ & & \\
\hline $699-49-79$ & $01 / 20 / 01$ & 194 & $\mathrm{U}$ & (no change) \\
\hline $699-51-75$ & $01 / 20 / 01$ & 194 & $\mathrm{U}$ & (no change) \\
\hline $699-51-75$ & $07 / 31 / 01$ & 190 & $\mathrm{U}$ & \\
\hline 699-51-75P & $01 / 20 / 01$ & 194 & $\mathrm{U}$ & (no change) \\
\hline
\end{tabular}




\section{Distribution}

No. of

Copies

ONSITE

6 DOE Richland Operations Office

M. J. Furman

R. D. Hildebrand

K. D. Leary

G. L. Sinton

A. E. Teimouri

K. M. Thompson

14 Fluor Hanford, Inc.

D. L. Flyckt

K. J. Lueck
No. of

Copies

P. M. Olson (10) S6-72

D. K. Smith S6-71

R. W. Szelmeczka S6-72

A5-13

A5-13

A6-38

$\mathrm{H} 0-12$

A5-15

A5-13

20 Pacific Northwest National Laboratory

D. B. Barnett (10)

K6-81

M. P. Bergeron

K9-36

M. J. Hartman

K6-96

S. P. Luttrell

K6-96

W. J. Martin

K6-81

J. T. Rieger (3)

K6-96

B. A. Williams

K6-96

Hanford Technical Library (2)

P8-55 